\title{
Mesograzers in Posidonia oceanica meadows: an update of data on gastropod-epiphyte-seagrass interactions
}

\author{
Esperança Gacia1,*, David Costalago², Patricia \\ Prado $^{1}$, Diana Piorno ${ }^{1}$ and Fiona Tomas ${ }^{3}$ \\ ${ }^{1}$ Centre d'Estudis Avançats de Blanes, CSIC, Ctra. \\ Accés Cala St. Francesc 14, 17300 Blanes, Spain, \\ e-mail: gacia@ceab.csic.es \\ ${ }^{2}$ Centre Mediterrani d'Investigacions Marines i \\ Ambientals, CSIC, Passeig Marítim de la Barceloneta, \\ 37-49, 08003 Barcelona, Spain \\ ${ }^{3}$ Institut Mediterrani d'Estudis Avançats, CSIC, \\ c/Miquel Marquès 21, 07190 Esporles, Palma de \\ Mallorca, Spain \\ * Corresponding author
}

\begin{abstract}
Information on dietary habits of mesograzers in Posidonia oceanica seagrass meadows is scarce and restricted to a few species. Here we provide data on the most likely food sources for eight gastropod species inferred from stable isotope data. We observed very similar isotopic signals for all species regardless of trophic guild category, indicating similar consumption behaviour with a main diet contribution from epiphytes. We also review the state of knowledge on gastropod-epiphyte-seagrass interactions, with particular emphasis on the scarcity of studies derived from Mediterranean systems. Laboratory experiments showed that under moderately nutrientenriched conditions, two species of gastropods (Bittium reticulatum and Jujubinus striatus) were controlling epiphyte biomass at high grazer densities, with no consequences for seagrass performance. Finally, the results of a long-term in situ fertilisation experiment showed that the $\delta^{15} \mathrm{~N}$ signal for seagrass, epiphytes and gastropods reflects experimentally induced eutrophication, thus cascading up nutrient effects throughout the food web.
\end{abstract}

Keywords: epiphytes; gastropods; grazing; nutrients; Posidonia oceanica; stable isotopes.

\section{Introduction}

Seagrass meadows shelter an important diversity of flora and fauna (Hemminga and Duarte 2000). One important component of this diversity is the vagile fauna, a group associated with seagrass blades and comprising small animals (crustaceans, molluscs, polychaetes) with reduced mobility. In Posidonia oceanica (L.) Delile meadows, gastropod molluscs are among the most important elements of this vagile fauna in terms of both species richness (Mazzella and Russo 1989, Gambi et al. 1991) and numbers of individuals (Ledoyer 1968, Kikuchi and Peres 1977, Templado et al. 2004). Gastropods form characteristic assemblages on leaves of $P$. oceanica, whereas leaf sheaths and rhizomes shelter species from the leaves and others from nearby infralitoral communities (macroalgal, coraligenous; Templado 1984a).

Seagrass leaf-associated gastropods generally feed on the epiphytic component, ingesting the biofilm composed of bacteria and diatoms, as well as various algal groups and animals (Van Montfrans et al. 1982, Kitting 1984, Mazzella et al. 1992). Gastropods have traditionally been assigned to different feeding guilds (Purchon 1968) coupled to the morphology of the feeding apparatus (radula) that constrains acquisition of food material and indirectly modulates the feeding resources for grazers (Steneck and Watling 1982) via selection of different food types (Peduzzi 1987, Mazzella and Russo 1989, Jernakoff and Nielsen 1997). These trophic abilities underlie our traditional understanding of feeding habits and dietary preferences of molluscs; for example, the diet of the herbivorous snail is based on the size, shape and toughness of a single algal species (Steneck and Watling 1982, Mazzella et al. 1992). Thus, trophic strategies of seagrass-associated gastropods are diverse and difficult to approach at the community level, but they can be relevant to the dynamics of the whole system (Phillippart 1995, Hughes et al. 2004).

Stable isotope analysis is an indirect method for identifying food pathways within complex ecosystems (Fry et al. 1987). In general, carbon (C) isotopes are used to identify the most likely carbon source of individual organisms (Fry and Sherr 1984), whereas nitrogen (N) isotopes are typically used to identify the trophic position of these organisms within the food web (Fry et al. 1987). The nitrogen isotopic signature at the consumer level can also be used to define foraging sites for organisms and the compositions of their diets relative to differences in $\mathrm{N}$ inputs (Shriver et al. 2002, Weiss et al. 2002, Carmichael et al. 2004, Vizzini and Mazzola 2004), and thus is a useful tool for tracking eutrophication phenomena (McClelland et al. 1997).

In Posidonia oceanica seagrass meadows, data on the relative contribution of different food sources have been investigated for macroherbivores (i.e., fish and sea urchins) using direct analyses of gut contents (Kempf 1962, Verlaque 1981), integrative stable isotope approaches (e.g., Havelange et al. 1997, Jennings et al. 1997, Vizzini and Mazzola 2004, 2006, Tomas et al. 2006, among others), or a combination of both (Pinnegar and Polunin 2000). Unfortunately, information on dietary habits of mesograzers is scarce, and for gastropods it is restricted to manipulative experiments designed to assess dietary preferences of Gibbula and Jujubinus spp. associated with P. oceanica (Peduzzi 1987, Mazzella and Russo 1989) and isolated data on stable isotopic compositions for a few species from the Bay of Calvi (Dauby 1989, Lepoint et al. 2000). Meadows of Zostera marina L. 
have been studied more comprehensively, with direct microscopic observation of seagrass leaf scars after grazing (Van Montfrans et al. 1982, Neckles et al. 1993) and, most recently, a combination of stable isotopes and fatty acid biomarkers for several gastropod species (Kharlamenko et al. 2001, Alfaro et al. 2006).

Interactions between grazers and epiphytes result in reductions in epiphyte biomass, increases in production and a shift in species composition (see the review by Jernakoff et al. 1996). For gastropods, direct data on grazing activity are scarce but there is experimental work showing epiphyte control by gastropods on Thalassia testudinum Banks et Sol. ex Koenig from Florida (Frankovich et al. 2003, Peterson et al. 2007), Zostera species from North America and Hong Kong (Neckles et al. 1993, Nelson 1997, Fong et al. 2000) and Posidonia sinuosa Cambridge et Kuo from Western Australia (Jernakoff and Nielsen 1997). In the Mediterranean Sea, although seagrasses can accumulate large amounts of epiphytes (Cebrián et al. 1999, Tomas et al. 2005), particularly the long-lived Posidonia oceanica, we do not know of any study on potential control of seagrass epiphyte biomass communities by mesograzers. Regulation of epiphyte overgrowth by grazers is particularly relevant under high nutrient conditions and may result in enhancement of seagrass productivity and/or survival. Hughes et al. (2004) compiled data on the impact of nutrients and the effects of grazers in 35 meadows worldwide. They mention only one reference for the Mediterranean Sea, viz. epiphyte overgrowth on the seagrass Cymodocea nodosa (Ucria) Ascherson, but no information on interaction with grazers is provided. More recently, studies on $P$. oceanica have shown that nutrient inputs cause an increase in epiphyte biomass and a shift in species composition (Prado et al. 2008) and promote macrograzer pressure under experimental (Prado 2007) and anthropogenic nutrient input gradients (Kirkman and Young 1981, Ruíz et al. 2001). However, there is still no information on whether mesograzers play a significant role in this seagrass-epiphyte interaction in the Mediterranean Sea.

The goals of the present study were: 1) to assess trophic guilds of gastropod molluscs living as vagile fauna on seagrass Posidonia oceanica using stable isotopes; 2) to experimentally examine the role of gastropods in regulating epiphyte biomass and its potential interaction with seagrass $P$. oceanica under laboratory conditions; and 3 ) to assess whether mesograzers reflect experimentally induced eutrophication following a long-term in situ experiment.

\section{Materials and methods}

All specimens used in this study (gastropods, seagrass and epiphytes) were collected in a shallow (7 $\mathrm{m}$ depth) Posidonia oceanica meadow growing over sand located off Fenals Point (NW Mediterranean Sea; Figure 1). Gastropods were identified and classified into trophic guild categories following Purchon (1968) and Steneck and Watling (1982).

\section{Trophic behaviour assessment using stable isotopes}

We collected gastropods of different species (minimum length $15 \mathrm{~mm}$ ) from the Fenals Posidonia oceanica meadow (Figure 1) and inferred food diet from the stable isotopic composition. Individuals were left for $24 \mathrm{~h}$ in seawater tanks to eliminate faeces and then stored frozen. To sort the snails, the shells were broken and the bodies extracted, making sure that there were no pieces of shell left. Gastropods were rinsed in distilled water, dried $\left(24 \mathrm{~h}, 60^{\circ} \mathrm{C}\right)$ and ground to a fine powder. Samples were sealed in glass vials for further isotope analysis. All species were collected in summer 2004.

Isotope abundances were measured on a continuousflow isotope radiomass spectrometer Delta C (Thermo Finnigan, Bremen, Germany) coupled to a Flash 1112 elemental analyser (Thermo Finnigan) through a Conflo III interface. Carbon and nitrogen were analysed in dual isotope mode. Samples of reference material (internal standards) were used to calibrate the system and compensate for drift with time. Experimental precision, based on the standard deviation of replicates of the internal standard, was $0.5 \%$ for both isotopes. The isotope ratios are expressed relative to the PeeDee Belemnite (PDB) standard for $\mathrm{C}$ and to $\mathrm{N}_{2}$ in air for $\mathrm{N}$. Isotope ratios were calculated as:

$\delta^{13} \mathrm{C}$ or $\delta^{15} \mathrm{~N}=\left[\left(\mathrm{R}_{\text {sample }} / \mathrm{R}_{\text {standard }}-1\right)\right] \times 1000$

where $R$ is the corresponding ${ }^{13} \mathrm{C} /{ }^{12} \mathrm{C}$ or ${ }^{15} \mathrm{~N} /{ }^{14} \mathrm{~N}$ ratio.

All analyses were performed at the Serveis CientíficoTècnics (University of Barcelona).

\section{Interaction between meso-herbivores, epiphytes and Posidonia oceanica under laboratory conditions}

To examine the interactions among gastropods, epiphytes and the seagrass Posidonia oceanica, we used 12 independent 10-I glass tanks filled with seawater. Ten $P$. oceanica shoots were placed in each tank, and four grazing treatments were allocated randomly: control (no grazers); 10 Jujubinus striatus L.; 20 J. striatus; and 20

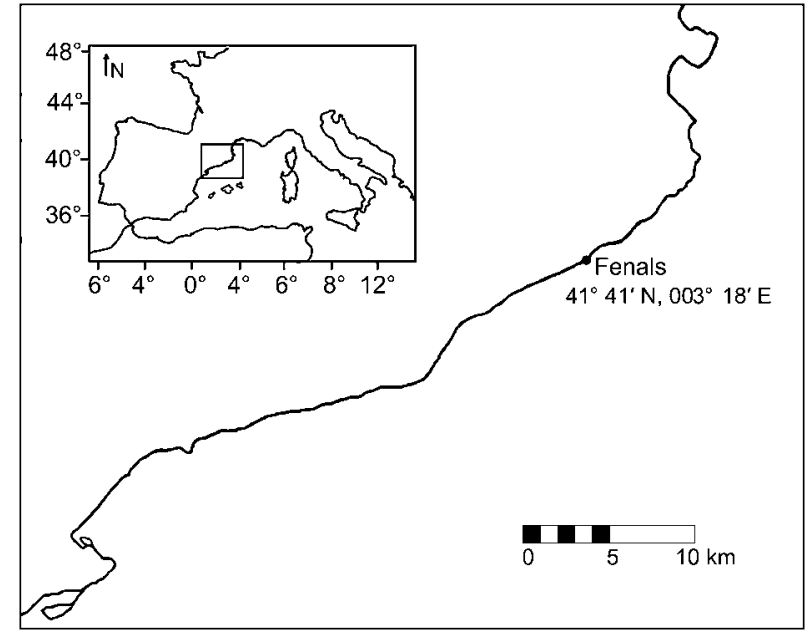

Figure 1 Posidonia oceanica: map of the study and sampling area at Fenals Point, northwestern Mediterranean Sea. 
Bittium reticulatum da Costa individuals. These densities correspond to the maximum values recorded at Fenals meadow (10 individuals of this size in $20 \times 20 \mathrm{~cm}^{2}$ ), plus two treatments with twice the maximum grazer densities recorded in the field. Tanks were kept under controlled light levels $\left(60-160 \mu \mathrm{mol}\right.$ photons $\left.\mathrm{m}^{-2} \mathrm{~s}^{-1}\right)$ at a daylength of $14 \mathrm{~h}$. The tank water was enriched with nutrients

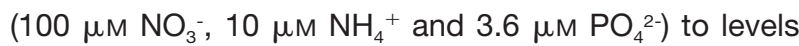
found at highly visited beaches nearby (Flo et al. 2007). The two gastropod species represent the most abundant herbivorous feeding guilds within seagrass meadows (grazing herbivores and herbivorous deposit-feeders) and, in contrast to natural conditions, they were applied separately in the different treatments. To estimate seagrass leaf growth (g dry wt [DW] shoot ${ }^{-1}$ ), shoots were marked by the punch-hole method (Romero 1989) at the beginning of the experiment (August 13, 2005). The experiment ran for 25 days and the tank water was changed every 5 days. At the end of the experiment, leaf elongation and the length and width of the marked shoots were measured. Epiphytes from the shoots collected were removed by scraping with a razor blade (Alcoverro et al. 1997). Shoots and epiphytes were then dried $\left(70^{\circ} \mathrm{C}\right.$ to constant weight) and weighed separately. The leaf growth rate (g DW shoot ${ }^{-1}$ day $^{-1}$ ) was determined by dividing the weight of new tissue (estimated from the relationship between leaf area and leaf DW) by the number of days elapsed since the marking event. Epiphyte load was determined as the epiphyte biomass per shoot (g DW shoot ${ }^{-1}$ ). We used nested ANOVA [fixed factor, grazing pressure (GP); nested random factor, tank] to test for differences in epiphyte biomass and seagrass growth. There were no significant differences in the initial plant conditions (number of leaves per tank; ANOVA, $F=0.92$, $n=12, p=0.52)$.

\section{Mesograzers as markers of eutrophication}

Following a long-term (1 year) in situ fertilisation experiment (Prado 2007), we investigated whether mesograzers would experimentally track induced eutrophication by collecting the most common gastropod (Bittium reticulatum) in the different treatment plots. The experimental design consisted of six seagrass patches (2-3 $\left.\mathrm{m}^{2}\right)$, three of them randomly assigned to a nutrient enrichment treatment, and the remaining three to controls. Nutrient enrichment was conducted monthly over 1 year using porous floating containers filled with a mixture of nutrient salts or Osmocote (Panreac, Heerlen, The Netherlands) slow release fertiliser (see Prado et al. 2008 for a full methodological description). Nutrient loading was not measured during the experiment because strong effects were clearly detected in plant and epiphyte $\mathrm{N}$ contents (Prado et al. 2008). Here we provide information on seasonal variation in the composition of the epiphytic community for the two treatments based on a functional form approach (Littler et al. 1983) using multi-dimensional scaling ordination (MDS). For stable isotope analyses, we collected 4-5 seagrass shoots and 4-12 B. reticulatum individuals (depending on natural abundances) from each plot. We also analysed the $\delta^{15} \mathrm{~N}$ signal of the fertiliser (see above for stable isotope analysis methodology). Owing to the limited amounts of gastropod material available, all individuals collected in a plot were pooled and thus differences in $\delta^{13} \mathrm{C}$ and $\delta^{15} \mathrm{~N}$ between treatments (controls vs. fertilised) were assessed using a t-test. For seagrass blades and epiphytes, however, we conducted nested ANOVAs [factor treatment (T) fixed, factor plot $(P)$ random and nested $\mathrm{P}(\mathrm{T})$ ]. When necessary, if the factor plot was not statistically significant, we pooled $P(T)$ with the residual to increase power with more degrees of freedom (Quinn and Keough 2002). Significant pairwise differences between means were tested using Tukey's test.

\section{Results}

\section{Trophic groups in gastropods}

We collected a total of 20 gastropods in eight taxa and three trophic guilds: grazing herbivore $(\mathrm{GH})$, depositfeeder herbivore $(\mathrm{DFH})$ and benthic hunter $(\mathrm{BH}$; Table 1). Representation of the different species in the biplot (Figure 2) shows that the carbon source for seagrassassociated gastropods (Table 2; mean \pm SD 18.52 \pm 0.51 , $n=20)$ is far from that for seagrass $(13.69 \pm 0.70, n=10)$, and close to that for the epiphytic community (19.21 $\pm 1.28, n=18) . \delta^{15} \mathrm{~N}$ values were slightly enriched in the gastropods (Table 2; 5.59 $\pm 0.61, \mathrm{n}=20$ ) compared to the primary producers $(3.23 \pm 0.38, \mathrm{n}=10$ for Posidonia oceanica leaves and $4.15 \pm 0.44, n=18$ for associated epiphytes). Within grazers, maximum variation in the $\delta^{15} \mathrm{~N}$ signal was 1.86 units and differences within trophic guilds were not significant (Table 3; Figure 3).

Table 1 Feeding guilds and radula types to which species collected in a Posidonia oceanica bed off Fenals (northwestern Mediterranean Sea) were assigned.

\begin{tabular}{lllll}
\hline Superorder & Family & Species & Feeding guild & Radula type \\
\hline Archeogastropoda & Trochidae & Jujubinus striatus & GH & Rhipidoglossan \\
& & Gibbula sp. & GH & Rhipidoglossan \\
& Calliostomatidae & Calliostoma sp. & GH & Rhipidoglossan \\
Caenogastropoda & Cerithium vulgatum Bruguière & DFH & Taenioglossan \\
& Cerithiidae & Bittium reticulatum & DFH & Taenioglossan \\
& Muricidae & Muricopsis cristata Brocchi & BH & Rachiglossan \\
& Nassaridae & Nassarius incrassatus Ström & BH & Rachiglossan \\
& Conidae & Mitromorpha sp. & BH & Rachiglossan \\
\hline
\end{tabular}

$\mathrm{GH}$, grazing herbivore; $\mathrm{DFH}$, deposit feeder herbivore; $\mathrm{BH}$, benthic hunter. 


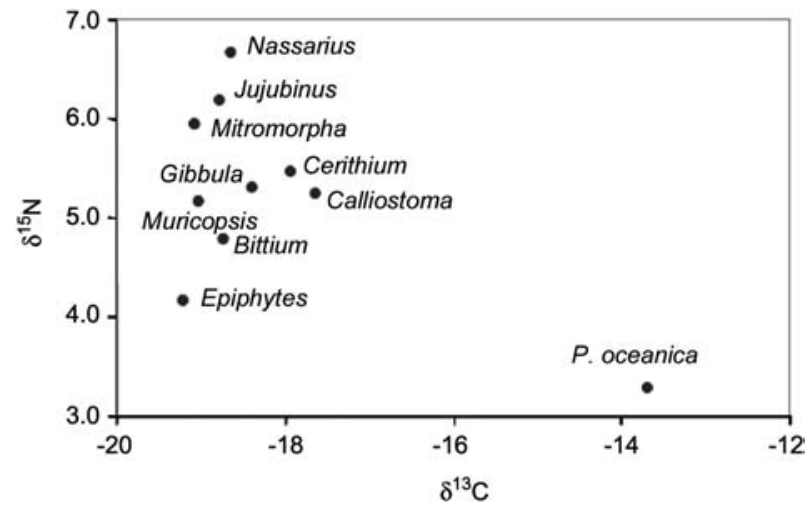

Figure 2 Stable isotope biplot for the different gastropod genera, epiphytes, and Posidonia (P.) oceanica from the Fenals meadow collected in summer 2004.

See Table 1 for more details on species identities.

\section{Experimental manipulation of gastropods}

After 25 days of experimental manipulation, we detected a significant effect of mesograzers in reducing epiphyte loading on Posidonia oceanica leaves (Table 4, Figure 4). The presence of gastropods reduced epiphyte biomass by $54-70 \%$ compared to controls; this effect was significant at high grazer densities (20 individuals) but not when 10 Jujubinus striatus individuals were present (Figure 4). When comparing the high grazer density treatments, epiphyte control by J. striatus was significantly higher than that by Bittium reticulatum (Figure 4). However, different gastropod densities did not result in differences in seagrass leaf production in terms of either biomass or surface area (Table 4).

\section{Mesograzers as tracers of eutrophication}

There were some differences in the composition of functional form groups of epiphytes from Posidonia oceanica undergoing in situ fertilisation compared to reference plots in spring and summer 2003 (Figure 5). Whereas bryozoans dominated in the control plots, filamentous algae proliferated in the fertilised plots in summer. Representation of the functional composition of the epiphytic community by treatments and season showed very similar epiphyte community composition across the experiment
Table 3 Results of the paired t-tests comparing the $\mathrm{C}$ and $\mathrm{N}$ isotope signals among the different trophic guilds.

\begin{tabular}{|c|c|c|c|c|c|c|}
\hline & \multicolumn{3}{|l|}{$\delta^{13} \mathrm{C}$} & \multicolumn{3}{|l|}{$\delta^{15} \mathrm{~N}$} \\
\hline & $\mathrm{GH}$ & DFH & $\mathrm{BH}$ & $\mathrm{GH}$ & DFH & $\mathrm{BH}$ \\
\hline $\mathrm{GH}$ & - & & & - & & \\
\hline DFH & 0.91 & - & & 0.42 & - & \\
\hline $\mathrm{BH}$ & 0.17 & 0.39 & - & 0.54 & 0.24 & - \\
\hline
\end{tabular}

Multiple pairwise comparisons without Bonferroni correction increase the possibility of a type I error. However, because there are no statistically significant differences at $p>0.05$ among groups, this does not affect the result. Values correspond to the two-tailed $p$-value. GH, grazing herbivore; DFH, deposit feeder herbivore; $\mathrm{BH}$, benthic hunter.

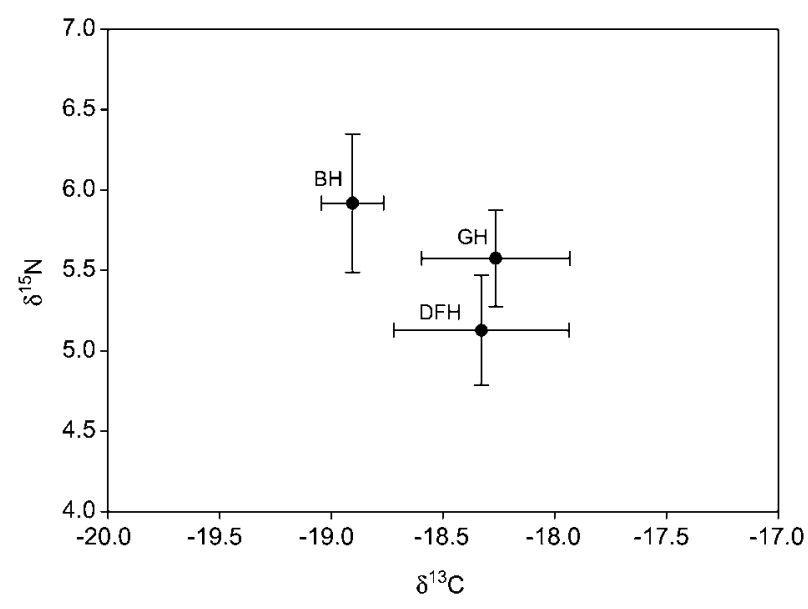

Figure 3 Mean $\pm S D$ values for the stable isotope biplots when grouping species by feeding guilds.

$\mathrm{G}$, grazing herbivores ( $\mathrm{n}=3$ species); $\mathrm{DFH}$, deposit feeder herbivores ( $n=2$ species); BH, benthic hunter ( $n=3$ species).

with the exception of samples from summer 2003 (Figure $6)$.

Fertilisation was detected in the $\delta^{15} \mathrm{~N}$ signals of seagrass, epiphytes and gastropods, which were consistently and significantly lower in fertilised than in control plots and in accordance with fertiliser values $\left(\delta^{15} \mathrm{~N}=0.4\right)$. However, we did not detect significant differences in $\delta^{13} \mathrm{C}$ among the different components of the food web (Table 5 , Figure 7) in accordance with the lack of differences in the composition of epiphyte communities in control and

Table 2 Means and standard deviations of the stable isotopic signals of mollusc species collected in a Posidonia oceanica meadow off Fenals.

\begin{tabular}{|c|c|c|c|c|c|}
\hline \multirow[t]{2}{*}{ Species } & \multirow[t]{2}{*}{$n$} & \multicolumn{2}{|l|}{$\delta^{13} \mathrm{C}$} & \multicolumn{2}{|l|}{$\delta^{15} \mathrm{~N}$} \\
\hline & & Mean & SD & Mean & SD \\
\hline Jujubinus striatus & 4 & -18.76 & 0.13 & 6.17 & 0.19 \\
\hline Gibbula sp. & 1 & -18.39 & & 5.30 & \\
\hline Calliostoma sp. & 1 & -17.64 & & 5.25 & \\
\hline Ceritium vulgatum & 1 & -17.94 & & 5.47 & \\
\hline Bittium reticulatum & 10 & -18.72 & 0.48 & 4.79 & 0.26 \\
\hline Muricopsis cristata & 1 & -19.03 & & 5.16 & \\
\hline Nassarius incrasatus & 1 & -18.63 & & 6.65 & \\
\hline Mitromorpha sp. & 1 & -19.06 & & 5.94 & \\
\hline Epiphytes & 18 & -19.21 & 1.28 & 4.15 & 0.44 \\
\hline Posidonia oceanica leaves & 10 & -13.69 & 0.70 & 3.27 & 0.38 \\
\hline
\end{tabular}

Data for epiphytes and Posidonia oceanica leaves are also included as a reference. 
Table 4 Summary of the nested ANOVAs [factor treatment $(T)$ fixed, factor plot $(P)$ random and nested $P(T)$ ] to test for significant differences in epiphyte biomass, seagrass leaf elongation and leaf production during the laboratory experiment to test for gastropodepiphyte-seagrass interactions.

\begin{tabular}{|c|c|c|c|c|}
\hline ANOVA & $\mathrm{df}$ & MS & $F$ & $p$ \\
\hline \multicolumn{5}{|l|}{ Epiphytic biomass } \\
\hline Treatment $=T$ & 3 & 0.129 & 8.261 & $<0.00110$ \\
\hline Tank=Tk (T) & 8 & 0.023 & 1.47 & 0.187 \\
\hline Residual & 60 & 0.0155 & & \\
\hline Cochran's C & & 0.239 & & \\
\hline Transformation & & $\sqrt{ } \sqrt{ } x$ & & \\
\hline \multicolumn{5}{|l|}{ Leaf elongation } \\
\hline Treatment $=\mathrm{T}$ & 3 & 0.977 & 0.9 & 0.447 \\
\hline Tank $=T k(T)$ & 8 & 5.48 & 5.059 & $<0.00110$ \\
\hline Residual & 60 & 1.0851 & & \\
\hline Cochran's C & & 0.193 & & \\
\hline Transformation & & None & & \\
\hline \multicolumn{5}{|l|}{ Leaf production } \\
\hline Treatment $=T$ & 3 & 0 & 0.321 & 0.81 \\
\hline Tank $=T k(T)$ & 8 & 0.003 & 2.284 & 0.033 \\
\hline Residual & 60 & 0.00143 & & \\
\hline Cochran's C & & 0.130 & & \\
\hline Transformation & & None & & \\
\hline
\end{tabular}

Grazing treatment (T), (no grazers, 10 Jujubinus, 20 Jujubinus and 20 Bittium); see Table 1 for species names. There were three tanks (P) per treatment containing 12 shoots each.

MS, mean square; df, degrees of freedom; p-values significant at 0.001 . Cochran's test used to test for homogeneity of variances, with $\mathrm{p}>0.05$ observed for all values. Values in bold indicate significant differences for the factor considered.
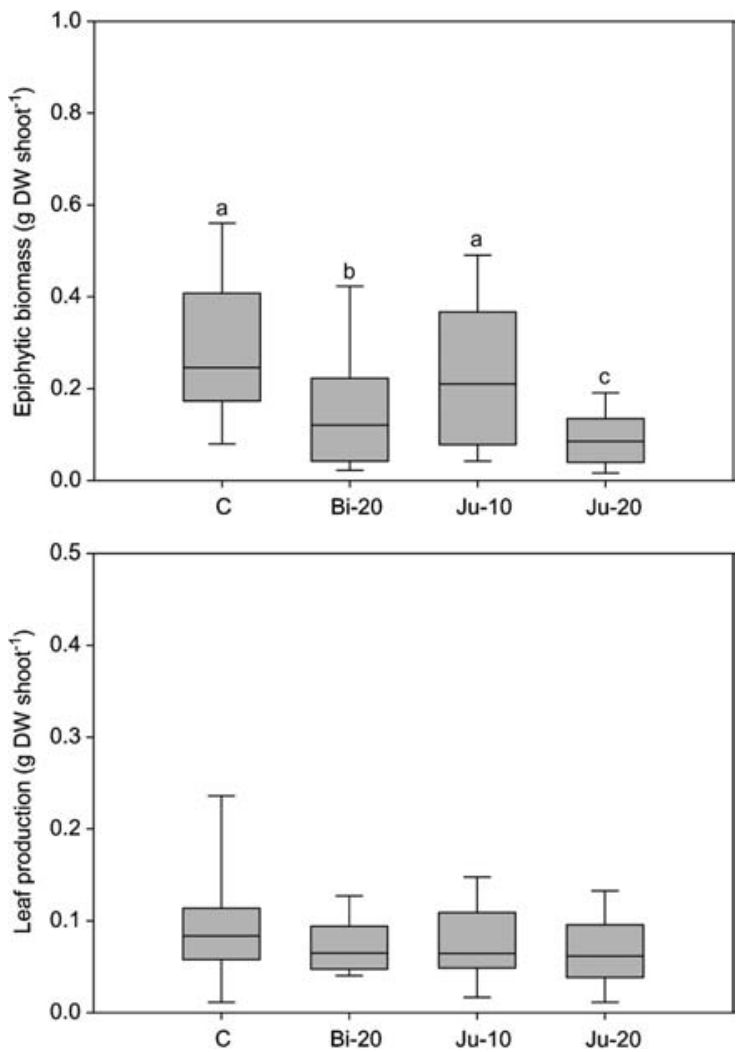

Figure 4 Epiphytic biomass and leaf production (in $\mathrm{g} \mathrm{DW}$ shoot $^{-1}$ ) at the end of the gastropod-epiphyte-seagrass interactions laboratory experiment.

C, control; Bi-20, 20 Bittium; Ju-10, 10 Jujubinus; Ju-20, 20 Jujubinus. Boxes encompass $50 \%$ of the values, the horizontal line represents the median value, and the bars extend to the $95 \%$ confidence limits. Different letters indicate statistically significant pairwise differences (Scheffé rank test $p<0.05$ ). fertilised plots throughout the year, with the exception of summer 2003.

\section{Discussion}

Gastropods collected in Fenals meadow are common species of the molluscan taxocoenosis of Posidonia oceanica (Templado 1984b, Russo 1991) and belong to three representative feeding guilds of the seagrass-associated assemblage (grazing herbivorous, herbivorousdeposit feeders and benthic hunters). Stable isotope data suggest that the main carbon source for this mesofauna is close to that of epiphytes, which is a common pattern for other consumers in meadows of $P$. oceanica (Dauby 1989, Lepoint et al. 2000, Vizzini et al. 2002). Differences in the nitrogen isotopic signature between grazers and epiphytes were lower than expected, suggesting ingestion of an alternative substrate. Seagrass tissue is not likely to be an optional food source because the structural characteristics of $P$. oceanica represent a mechanical obstruction for the animals' feeding apparatii (radula; authors' unpublished data). The $\delta^{15} \mathrm{~N}$ signals for macroepiphytes are thought to be higher than those of the epiphytic biofilm, where the presence of cyanobacteria would lower the signal in relation to the overall community (Lepoint et al. 2000); gastropods (from eelgrass meadows) that consume large amounts of diatoms and bacteria have $\delta^{15} \mathrm{~N}$ signals close to those of epiphytes (Kharlamenko et al. 2001, Alfaro et al. 2006).

The similar $\mathrm{C}$ and $\mathrm{N}$ isotopic signatures among species belonging to different trophic guilds indicate that adult gastropods living in the Fenals seagrass meadow con- 

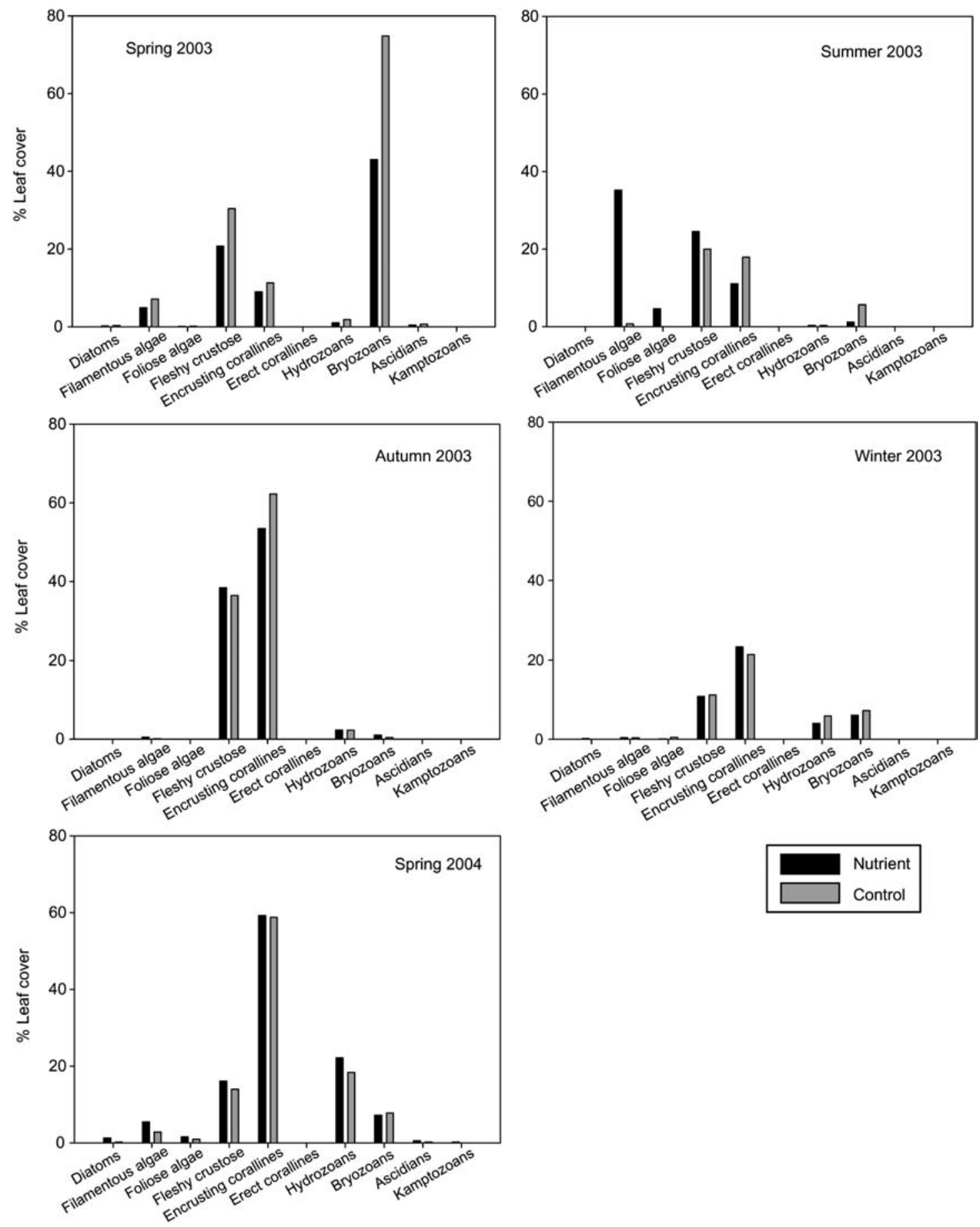

Figure 5 Impact of a year-long fertilisation experiment (see materials and methods section and Prado et al. 2008) on the functional group composition of the epiphytic community on Posidonia oceanica.

sume analogous substrates; thus, they do not conform to the feeding differentiation by trophic guild in traditional systems based on morphometric parameters (Steneck and Watling 1982). Similar results were found in a Zostera capricorni Asch. meadow, where $\delta^{15} \mathrm{~N}$ for predatory snails did not differ from that for grazing snails (Alfaro et al. 2006). Further studies should assess whether the feeding pattern encountered for gastropods associated with Posidonia oceanica is consistent throughout the year or varies seasonally with macro-epiphyte consumption (e.g., in eelgrass meadows, Neckles et al. 1993). Nevertheless, there is increasing evidence that the discrimination factors typically used to establish the relative contribution of different food sources can vary substantially (Vanderklift and Ponsard 2003), and thus proper interpretation of field stable isotope data should consider controlled laboratory experiments that allow specific determination of enrichment factors between diets and consumers (Crawley et al. 2007). Furthermore, the manipulative experiment we conducted highlights the fact that gastropods can exert strong control on epiphyte biomass, at least under high densities in slightly eutrophic conditions. We did not record the composition of the epiphytic community, but differences in epiphyte biomass seem to support the notion that eutrophic conditions would favour food webs based on algae, whereas 


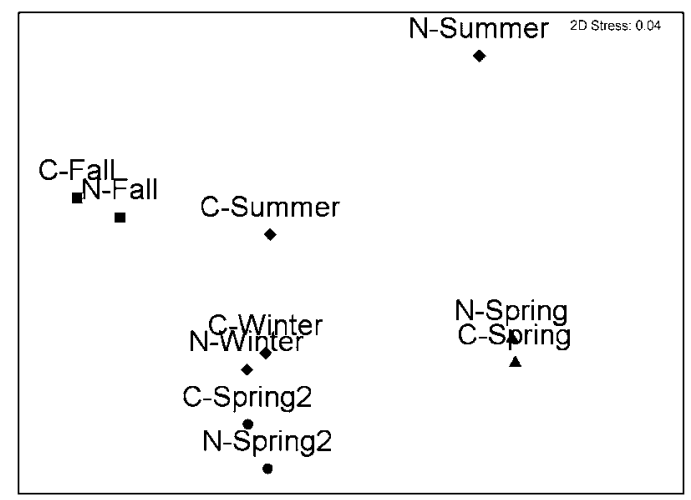

Figure 6 MDS ordination of the functional group composition in the Posidonia oceanica epiphytic community in the long-term fertilisation experiment.

$\mathrm{N}$, nutrient enriched; C, control treatments.

oligotrophy would favour seagrass detritus and/or biofilm-based consumption (Dauby and Poulicek 1995). Similarly, Fry et al. (1987) pointed out that nutrient availability might govern the trophic importance of epiphytic algae in seagrass meadows.

The two trochids used in the laboratory experiment, Bittium reticulatum and Jujubinus striatus, were dominant mesograzers in the meadow studied and were commonly found during daylight hours on leaves of Posidonia oceanica at densities that would not have allowed significant control of the epiphyte biomass in our experiment. However, our experiment might have underestimated the potential effect of grazers on epiphyte control because numerous species with day-night migratory patterns from rhizomes to leaves (Templado et al. 2004) were not included. However, mesograzer-induced epiphyte reduction might not have had positive effects on the seagrass because epiphytes tend to accumulate on older leaves, which contribute least to the overall carbon balance of the plant (Alcoverro et al. 2004). A similar result with a lack of effect on the seagrass was found in manipulative experiments with the main invertebrate macrograzer in $P$. oceanica meadows [the sea urchin Paracentrotus lividus (Lamarck), Tomas et al. 2005]. Further studies examining the effect over a longer time period are necessary because $P$. oceanica growth is prone to inertia (Alcoverro et al. 2001), which might have hidden a shading effect by epiphytes. Alternatively, reduced light availability in the experimental conditions (levels below saturation; Alcoverro et al. 2001) might have constrained the growth potential of the plants in the grazed treatments.

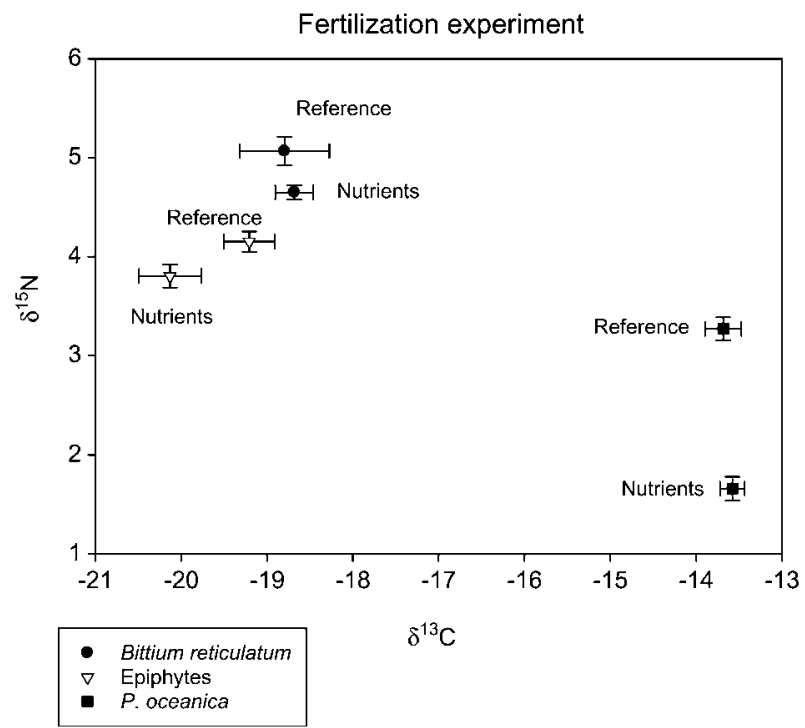

Figure 7 Isotopic signal biplot for seagrass, epiphytes and Bittium reticulatum collected in June 2004 in fertilised (nutrients) and reference plots after a 1-year fertilisation experiment. Nutrients, three plots; reference, three plots; $n=4-12$ B. reticulatum individuals per plot. t-test for $\delta^{15} \mathrm{~N} \mathrm{p}<0.04$ and for $\delta^{13} \mathrm{C}$ $\mathrm{p}=0.81$. Values are mean $\pm \mathrm{SD} ; \mathrm{n}=10$ for Posidonia $(P$.) oceanica and $\mathrm{n}=20$ for epiphytes.

Nitrogen isotopic signals were used to trace experimentally induced fertilisation in the system examined, although differences in $\delta^{15} \mathrm{~N}$ between control and fertilised treatments were not maintained throughout the food web. Whereas seagrass $\delta^{15} \mathrm{~N}$ was strongly influenced by the fertiliser signal and was very different from the signal for control plots, isotopic signals for epiphytes and mesograzers were closer between treatments (although the influence of the lower $\delta^{15} \mathrm{~N}$ from the fertiliser was still detectable in both cases). However, the lack of changes detected in $\delta^{13} \mathrm{C}$ of epiphytes might reflect a similar community composition between control and nutrientenriched experiments throughout the year (with the single exception of summer data).

\section{Conclusion}

The main adult gastropods associated with leaves of Posidonia oceanica seem to feed on the epiphytic component (based on their carbon isotopic signature) in a shallow meadow off the Catalan coast. Information on the nitrogen isotopic signature suggests that there is

Table 5 Summary of the nested ANOVAs to test for significant differences in carbon and nitrogen stable isotope signals in the longterm fertilisation experiment (see Prado et al. 2008 for more details).

\begin{tabular}{|c|c|c|c|c|c|c|c|c|c|c|}
\hline \multirow{2}{*}{$\begin{array}{l}\text { Dependent } \\
\text { variable }\end{array}$} & \multirow[t]{2}{*}{ Treatment } & \multicolumn{3}{|l|}{$\delta^{13} \mathrm{C}$} & \multirow[t]{2}{*}{$p$} & \multirow[t]{2}{*}{ Treatment } & \multicolumn{3}{|l|}{$\delta^{15} \mathrm{~N}$} & \multirow[t]{2}{*}{$\mathrm{p}$} \\
\hline & & MS & $d f$ & $F$ & & & MS & df & $F$ & \\
\hline \multirow[t]{2}{*}{ Seagrass } & Fertilisation & 0.059 & 1 & 0.17 & $0.689^{\star}$ & Fertilisation & 10.53 & 1 & 28.18 & 0.033 \\
\hline & Error & 0.353 & 18 & & & $\begin{array}{l}\text { Plot } \\
\text { Error }\end{array}$ & $\begin{array}{l}0.38 \\
0.11\end{array}$ & $\begin{array}{r}2 \\
16\end{array}$ & 3.45 & 0.057 \\
\hline \multirow[t]{3}{*}{ Epiphytes } & Fertilisation & 7.46 & 1 & 7.89 & $0.038^{* *}$ & Fertilisation & 1.285 & 1 & 4.75 & $0.035^{\star}$ \\
\hline & Plot & 0.88 & 4 & 0.33 & 0.856 & Error & 0.271 & 41 & & \\
\hline & Error & 2.67 & 37 & & & & & & & \\
\hline
\end{tabular}

MS, mean square; df, degrees of freedom; significant differences between treatments at $p<0.05$ are in bold.

* After pooling data; ${ }^{* *}$ no homogeneity of variance achieved; $\alpha<0.01$. 
selection for some of the epiphytes, with a major contribution from micro-epiphytes (diatoms and bacteria), which have lighter signatures. Carbon and nitrogen isotopic signatures of species belonging to different trophic guild categories did not show significant differences, indicating similar feeding substrates. Experimental testing of the potential effect of gastropods on modulating seagrass-epiphyte interaction following eutrophication revealed significant control of the epiphyte biomass by grazers at high gastropod densities, although this had no consequences for seagrass performance. This study highlights the necessity for further work to elucidate the diets of the overall gastropod assemblage associated with $P$. oceanica in a wide range of meadows and the use of additional tools (fatty acid biomarkers) to completely understand the feeding behaviour of gastropods in this seagrass ecosystem. Moreover, although preliminary data for high-density single-species treatments suggest that gastropods do not have any effect on $P$. oceanica growth, further studies over longer time periods and using more complete mesograzer assemblage should help to identify the role of grazers in seagrassepiphyte interactions in the Mediterranean Sea. Bittium reticulatum did reflect experimentally induced eutrophication, cascading up nutrient effects throughout the food web over the long term in an in situ fertilisation experiment.

\section{Acknowledgements}

This work was supported by the FUNPOS project (Plan Nacional I+D, MEC ref. 2006301006). David Costalago was funded by MEC under the I3P postgrado programme and Diana Piorno is the recipient of a La Caixa pre-doctoral fellowship (2006-2008). We thank two anonymous referees for their useful comments.

\section{References}

Alcoverro, T., J. Romero, C.M. Duarte and N.I. López. 1997. Spatial and temporal variations in nutrient limitation of seagrass Posidonia oceanica growth in the NW Mediterranean. Mar. Ecol. Prog. Ser. 146: 155-161.

Alcoverro, T., M. Manzanera and J. Romero. 2001. Annual metabolic carbon balance of the seagrass Posidonia oceanica: the importance of carbohydrate reserves. Mar. Ecol. Prog. Ser. 211: 15-116.

Alcoverro, T., M. Perez and J. Romero. 2004. Importance of within-shoot epiphyte distribution for the carbon budget of seagrasses: the example of Posidonia oceanica. Bot. Mar. 47: 307-312.

Alfaro, A.C., F. Thomas, L. Sergent and M. Duxbury. 2006. Identification of trophic interactions within an estuarine food web (northern New Zealand) using fatty acid biomarkers and stale isotopes. Estuar. Coast. Shelf Sci. 70: 271-286.

Carmichael, R.H., D. Rutecki, B. Annett, E. Gaines and I. Valiela. 2004. Position of horseshoe crabs in estuarine food webs: $N$ and $C$ isotopic study of foraging ranges and diet composition. J. Exp. Mar. Biol. Ecol. 299: 231-253.

Cebrián, J., S. Enríquez, M. Fortes, N.S.R. Agawin, J. Vermaat and C.M. Duarte. 1999. Epiphyte accrual on Posidonia oceanica (L.) Delile leaves: implications on light absorption. Bot. Mar. 42: 123-128.
Crawley, K.R., G.A. Hyndes and M.A. Vanderklift. 2007. Variation among diets in discrimination of $\delta^{13} \mathrm{C}$ and $\delta^{15} \mathrm{~N}$ in the amphipod Allorchestes compressa. J. Exp. Mar. Biol. Ecol. 349: 370-377.

Dauby, P. 1989. The stable carbon isotope ratios in benthic food webs of the Gulf of Calvi, Corsica. Cont. Shelf Res. 9: 181-195.

Dauby, P. and M. Poulicek. 1995. Methods for removing epiphytes from seagrasses: SEM observations on treated leaves. Aquat. Bot. 52: 217-228.

Flo, E., J. Camp, M. Manzanera, M. De Torres. 2007. Informe final correspondiente al Programa de Vigilància i Control Ambiental de les Aigües Litorals a Catalunya [Convenio CV03000043, Agència Catalana de I'Aigua (ACA) Generalitat de Catalunya y Institut de Ciències del Mar (ICM), CSIC]. Technical report. $83 \mathrm{pp}$.

Fong, C.W., S.Y. Lee and R.S.S. Wu. 2000. The effects of epiphytic algae and their grazers on the intertidal seagrass Zostera japonica. Aquat. Bot. 67: 251-261.

Frankovich, T.A., J.C. Zieman, B.J. Peterson and J.W. Fourqurean. 2003. Nutrients, gastropod grazers, and seagrass leaf turnover rate as controls of epiphyte loading on Thalassia testudinum. Gulf Mex. Sci. 21: 114-115.

Fry, B. and E.B. Sherr. 1984. $\delta^{13} \mathrm{C}$ measurements as indicators of carbon flow in marine and freshwater ecosystems. Contr. Mar. Sci. 27: 13-47.

Fry, B., S.A. Macko and J.C. Zieman. 1987. Review of stable isotope investigation of food webs in seagrass meadows. Fla. Mar. Res. Publ. 42: 189-209.

Gambi, M.C., A. Giangrande, M. Martinelli and L.A. Chessa. 1991. Polychaetes of the Mediterranean seagrass Posidonia oceanica: spatio-temporal distribution and feeding guild analysis. Sci. Mar. 59: 129-141.

Havelange, S., G. Lepoint, P. Dauby and J.M. Bouquegnau. 1997. Feeding of the sparid fish Sarpa salpa in a seagrass ecosystem: diet and carbon flux. PSZNI Mar. Ecol. 18: 289-297.

Hemminga, M.A. and C.M. Duarte. 2000. Seagrass ecology. Cambridge University Press, Cambridge. 292 pp.

Hughes, A.R., K.J. Bando, L.F. Rodriguez and S.L. Williams. 2004. Relative effects of grazers and nutrients on seagrasses: a meta-analysis approach. Mar. Ecol. Prog. Ser. 287: 97-99.

Jennings, S., O. Reñones, B. Morales-Nin, N.V.C. Polunin, J. Moranta and J. Coll. 1997. Spatial variation in the ${ }^{15} \mathrm{~N}$ and ${ }^{13} \mathrm{C}$ stable isotope composition of plants, invertebrates and fishes on Mediterranean reefs: implications for the study of trophic pathways. Mar. Ecol. Prog. Ser. 146: 109-116.

Jernakoff, P. and J. Nielsen. 1997. The relative importance of amphipod and gastropod grazers in Posidonia sinuosa meadows. Aquat. Bot. 56: 183-202.

Jernakoff, P., A. Brearley and J. Nielsen. 1996. Factors affecting grazer-epiphyte interactions in temperate seagrass meadows. Oceanogr. Mar. Biol. Annu. Rev. 34: 109-162.

Kempf, M. 1962. Recherches d'ecologie comparee sur Paracentrotus lividus (Lmk.) et Arbacia lixula (L.). Rec. Trav. Stn. Mar. Endoume 25: 47-116.

Kharlamenko, V.I., S.I. Kiyashko, A.B. Imbs and D.I. Vyshkvartzev. 2001. Identification of food sources of invertebrates from the seagrass Zostera marina community using carbon and sulfur stable isotope ratio and fatty acid analysis. Mar. Ecol. Prog. Ser. 220: 103-117.

Kikuchi, T. and J.M. Peres. 1977. Consumer ecology of seagrass beds. In: (C.P. McRoy and C. Hefferich, eds.) Seagrass ecosystems. Marcel Dekker, New York. pp. 147-193.

Kirkman, H. and P.C. Young. 1981. Measurement of health, and echinoderm grazing on Posidonia oceanica (L.) Delile. Aquat. Bot. 10: 329-338.

Kitting, C.L. 1984. Selectivity by dense populations of small invertebrates foraging among seagrass blade surfaces. Estuaries 7: 276-288. 
Ledoyer, M. 1968. Ecologie de la faune vagile des biotopes méditerranéens accessibles en scaphandre autonome (Région de Marseille principalement) IV. Synthèse de l'étude écologique. Rec. Trav. St. Mar. Endoume 44: 126-295.

Lepoint, G., F. Nyssen, S. Gobert, P. Dauby and J.M. Bouquegenau. 2000. Relative impact of a seagrass bed and its adjacent epilithic algal community in consumer diets. Mar. Biol. 136: 513-518.

Littler, M.M., D.S. Littler and P.R. Taylor. 1983. Evolutionary strategies in a tropical barrier reef system: functional-form groups of marine macroalgae. J. Phycol. 19: 229-237.

Mazzella, L. and G.F. Russo. 1989. Grazing effect of two Gibbula species (Mollusca, Archaeogastropoda) on the epiphytic community of Posidonia oceanica leaves. Aquat. Bot. 35: 357-373.

Mazzella, L., M.C. Buia, M.C. Gambi, M. Lorenti, G.F. Russo, M.B. Scipione and V. Zupo. 1992. Plant-animal trophic relationships in the Posidonia oceanica ecosystem of the Mediterranean Sea: a review. In: (D.M. John, S.J. Hawkins and J.H. Price, eds.) Plant-animal interactions in the marine benthos. Clarendon Press, Oxford. pp. 165-187.

McClelland, J.W., I. Valiela and R.H. Michener. 1997. Nitrogenstable isotope signatures in estuarine food webs: a record of increasing urbanization in coastal watersheds. Limnol. Oceanogr. 42: 930-937.

Neckles, H.A., R.L. Wetzel and R.J. Orth. 1993. Relative effects of nutrient enrichment and grazing on epiphyte-macrophyte (Zostera marina L.) dynamics. Oecologia 93: 285-295.

Nelson, T.A. 1997. Epiphyte-grazer interactions on Zostera marina (Anthophyta, Monocotiledones): effects of density on community function. J. Phycol. 33: 743-752.

Peduzzi, P. 1987. Dietary preferences and carbon absorption by two grazing gastropods: Gibbula umbilicaris and Jujubinus striatus. PSZNI Mar. Ecol. 8: 359-370.

Peterson, B.J., T.A. Frankovich and J.C. Zieman. 2007. Response of seagrass epiphyte loading to field manipulations of fertilization, gastropod grazing and leaf turnover rates. J. Exp. Mar. Biol. Ecol. 349: 61-72.

Phillippart, C.J.M. 1995. Effect of periphyton grazing by Hydrobia ulvae on the growth of Zostera noltii on a tidal flat in the Dutch Wadden Sea. Mar. Biol. 122: 431-437.

Pinnegar, J.K. and N.V.C. Polunin. 2000. Contributions of stableisotope data to elucidating food webs of Mediterranean rocky littoral fishes. Oecologia 122: 399-409.

Prado, P. 2007. Magnitude of herbivory in Posidonia oceanica and factors responsible for spatial variation. PhD thesis, University of Barcelona. $182 \mathrm{pp}$.

Prado, P., T. Alcoverro and J. Romero. 2008. Seasonal response of Posidonia oceanica epiphyte assemblages to nutrient increase. Mar. Ecol. Prog. Ser. 359: 89-98.

Purchon, R.D. 1968. The biology of the Mollusca. Pergamon Press, Oxford. 560 pp.

Quinn, G.P. and M.J. Keough. 2002. Experimental design and data analysis for biologists. Cambridge University Press, Cambridge. pp. 615.

Romero, J. 1989. Seasonal pattern of Posidonia oceanica production: growth, age and renewal of leaves. In: (C.F. Boudouresque, A. Meinesz, E. Fresi and V. Gravez, eds.) International workshop on Posidonia beds 2. GIS Posidonie, Marseille. pp. 63-67.

Ruíz, J.M., M. Pérez and J. Romero. 2001. Effects of fish farm loadings on seagrass (Posidonia oceanica) distribution, growth and photosynthesis. Mar. Pollut. Bull. 42: 749-760.

Russo, G.F., L.A. Chessa, D. Vinci and E. Fresi. 1991. Molluscs of Posidonia oceanica beds in the bay of Porto Conte (Northwestern Sardinia): zonation pattern, seasonal variability and geographical comparison. Posidonia Newsletter 4: 5-14.

Shriver, A.C., R.H. Carmichael and I. Valiela. 2002. Growth, condition, reproductive potential, and mortality of bay scallops, Argopecten irradians, in response to eutrophic-driven changes in food resources. J. Exp. Mar. Biol. Ecol. 279: 21-40.

Steneck, R.S. and L. Watling. 1982. Feeding capabilities and limitation of herbivorous molluscs: a functional group approach. Mar. Biol. 68: 299-319.

Templado, J. 1984a. Moluscos de las praderas de Posidonia oceanica en las costas del cabo de Palos (Murcia). Inv. Pesqueras 48: 509-526.

Templado, J. 1984b. Las praderas de Posidonia oceanica en el sureste español y su biocenosis. In: (C.F. Boudouresque, A. Jeudy de Grissac and J. Olivier, eds.) International Workshop on Posidonia oceanica beds. GIS Posidonie, Marseille. pp. 159-172.

Templado, J., M. Calvo, A.A. Luque, A. Garvía, M. Maldonado and L. Moro. 2004. Guía de los invertebrados y peces marinos españoles protegidos por la legislación nacional e internacional. Ministerio de Medio Ambiente, Serie Técnica, Madrid. $269 \mathrm{pp}$

Tomas, F., X. Turon and J. Romero. 2005. Effects of herbivores on a Posidonia oceanica seagrass meadow: importance of epiphytes. Mar. Ecol. Prog. Ser. 287: 15-125.

Tomas, F., D. Alvarez-Cascos, X. Turon and J. Romero. 2006. Differential element assimilation by sea urchins Paracentrotus lividus in seagrass beds: implications for trophic interactions. Mar. Ecol. Prog. Ser. 306: 125-131.

Vanderklift, M.A. and S. Ponsard. 2003. Sources of variation in consumer-diet $\delta^{15} \mathrm{~N}$ enrichment: a meta-analysis. Oecologia 136: 169-182.

Van Montfrans, J., R.J. Orth and S.A. Vay. 1982. Preliminary studies of grazing by Bittium varium on eelgrass periphyton. Aquat. Bot. 14: 75-89.

Verlaque, M. 1981. Preliminary data on some Posidonia oceanica feeders. Rapp. Comm. Int. Mer Médit. 27: 201-202.

Vizzini, S. and A. Mazzola. 2004. Stable isotope evidence for the environmental impact of a land-based fish farm in the western Mediterranean. Mar. Pollut. Bull. 49: 61-70.

Vizzini, S. and A. Mazzola. 2006. Sources and transfer of organic matter in food webs of a Mediterranean coastal environment: Evidence for spatial variability. Estuar. Coast Shelf Sci. 66: 459-467.

Vizzini, S., G. Sarà, R.H. Michener and A. Mazzola. 2002. The trophic role of the macrophyte Cymodocea nodosa (Ucria) Asch. in a Mediterranean saltworks: evidence from carbon and nitrogen stable isotope ratios. Bull. Mar. Sci. 71: 13691378.

Weiss, E.T., R.H. Carmichael and I. Valiela. 2002. The effect of nitrogen loading on the growth rates of quahogs (Mercenaria mercenaria) and soft-shell clams (Mya arenaria) through changes in food supply. Aquaculture 211: 275-289.

Received 31 October, 2008; accepted 19 May, 2009; online first 5 August, 2009 